\title{
A Study of Serological Markers of Hepatitis B and C Viruses in Istanbul, Turkey
}

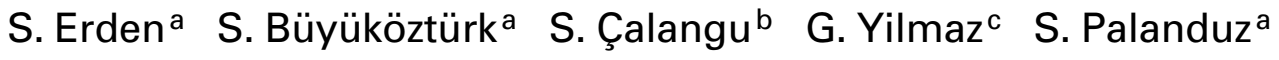 \\ S. Badurc \\ Departments of a Internal Medicine, ${ }^{b}$ Clinical Infectious Diseases and ${ }^{\mathrm{c}}$ Microbiology, Faculty of Medicine, \\ Istanbul University, Istanbul, Turkey
}

\section{Key Words}

Hepatitis B surface antigen - Anti-HBs · Anti-hepatitis C virus · Hepatitis B marker · Hepatitis $C$ marker

\begin{abstract}
Objective: This study was undertaken to investigate the prevalence of HBsAg, anti-HBs and anti-HCV positivity in Istanbul, Turkey. Subjects and Methods: The frequencies of HBsAg, anti-HBs and anti-HCV positivity were determined in 1,157 randomly selected patients attending the outpatient clinic of Istanbul University Hospital, Istanbul, Turkey, during the years 1998 and 2001. All patients underwent complete physical and various routine laboratory examinations. Results: Of the 1,157 patients, the prevalence of $\mathrm{HBsAg}$, anti-HBs and anti-HCV was 6.6, 28.1 and $2.4 \%$, respectively. It appeared that having dental and surgical procedures formed the risk factors for HBV infection. HBsAg positivity in the health care workers was not different from that of the other professions, but anti-HBs was significantly higher in this group. Conclusions: Our findings indicate that HBV infection occurs more frequently than HCV in Istanbul, and this poses an important health problem in the community.
\end{abstract}

Copyright $\odot 2003$ S. Karger AG, Basel

\section{Introduction}

Viral hepatitis which is widely seen all over the world is one of the most important health problems in Turkey. Approximately 200,000 people suffer acute viral hepatitis in Turkey each year, and about 4 million people are hepatitis virus carriers [1]. A routine hepatitis $B$ vaccination program for neonates was established in 1998. Its application rate is approximately $81 \%$ for the whole country.

Many investigations have been done on the prevalence of hepatitis $\mathrm{B}(\mathrm{HBV})$ and hepatitis $\mathrm{C}(\mathrm{HCV})$ infections in Turkey. Most of these studies were conducted on blood donors and the results obtained from different regions of Turkey showed some differences as for example, 10.8\% hepatitis B surface antigen (HBsAg) positivity reported in 1991 from Eskisehir and 2.4\% in 1994 from Izmir [1]. In this study, we aimed to determine HBsAg, anti-HBs and anti-HCV prevalence in a population consisting of patients who attended the outpatient clinic of the Department of Internal Medicine, University Hospital, Istanbul, Turkey.

\section{KARGER \\ Fax +4161306 1234 \\ E-Mail karger@karger.ch \\ www.karger.com

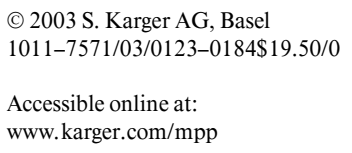

Dr. Sükrü Palanduz

Istanbul University, Istanbul Medical Faculty

Department of Internal Medicine, Division of Medical Genetics

Capa, Istanbul 34093 (Turkey)

Fax+90212 4111393, E-Mail spalanduz@istanbul.edu.tr 


\section{Subjects and Methods}

In the present study, 1,404 subjects were examined over a period of 3 years, between 1998 and 2001, approximately 300 patients per day. The study group was randomly selected among those patients who came to the outpatient clinic for various reasons, and those who came specifically to be checked for hepatitis. Patients' consent was obtained verbally. Two hundred and forty-seven patients with hepatic disease and HBV vaccination or who were close relatives of HBV carriers were initially entered in the study, but were subsequently analyzed separately. Of the remaining 1,157 subjects, 371 were born in Istanbul and 786 in other parts of the country; 836 were female and 321 male. Age range of the patients was 15-85 years, with an average of $37.6 \pm 16.2$. Average age of females was $38.5 \pm 15.8$ years, and that of males was $35.7 \pm 16.9$ years. All patients had undergone a complete physical examination and routine laboratory examinations.

A previously described micro-ELISA method was used to analyze for HBsAg, anti-HBs and anti-HCV [2]. Whole blood samples were drawn and clotted; the sera were separated by centrifugation and stored at $2-8^{\circ} \mathrm{C}$ for up to 7 days. Hepanostica HBsAg, Hepanostica

Table 1. The distribution of subjects according to gender

\begin{tabular}{llcr}
\hline Serologic marker & $\begin{array}{l}\text { Male } \\
(\mathrm{n}=321)\end{array}$ & $\begin{array}{l}\text { Female } \\
(\mathrm{n}=836)\end{array}$ & \multicolumn{1}{l}{$\begin{array}{l}\text { Total } \\
(\mathrm{n}=1,157)\end{array}$} \\
\hline HBsAga $^{\mathrm{a}}$ & $39(12.1 \%)^{\mathrm{d}}$ & $38(4.5 \%)$ & $77(6.6 \%)$ \\
Anti-HBs $^{\mathrm{b}}$ & $79(24.6 \%)$ & $247(29.5 \%)$ & $326(28.1 \%)$ \\
Anti-HCV $^{\mathrm{c}}$ & $12(3.7 \%)$ & $16(1.9 \%)$ & $28(2.4 \%)$
\end{tabular}

a Male vs. female HBsAg: $p<0.0001$ (extremely significant).

Male vs. female anti-HBs: $\mathrm{p}=0.093$.

Male vs. female anti-HCV: $\mathrm{p}=0.086$.

d The percentage in parentheses relates to the total number of patients in that gender group.
anti-HBs and UBIHCV E1A 4.0 kits (Organon, Teknika) were used for testing the serological markers. The elements of quality control program for ELISA were included with in-run and between-run control measurements. The results obtained were analyzed with SPSS version 7.0 [3]. Descriptive analysis was used to find out the rates of serological markers. Prevalence rates of HBsAg positivity, anti-HBs and anti-HCV were analyzed according to age, risk, professional background and geographical region of birth. The risks used for classification were undergoing dental procedures, surgery, gynecological interventions, having blood transfusion, working in the health care sector and being related to carriers. The results of these subgroups were compared with Fisher's exact test.

\section{Results}

Among the total patient population of 1,404, a group of 247 , with a history of hepatitis or close relationship with HBV carriers, had a HBsAg rate of $33.4 \%$ and therefore were excluded from further statistical analysis. Of the remaining 1,157 patients, HBsAg positivity was found in 77 cases $(6.6 \%)$, anti-HBs positivity in 326 persons $(28.1 \%)$, and anti-HCV positivity in $28(2.4 \%)$. The rate of HBsAg in males and females was 12.1 and $4.5 \%$, respectively $(\mathrm{p}<0.0001)$. The corresponding rate of antiHBs in males and females was 24.6 and $29.5 \%(\mathrm{p}=0.093)$ while the rate of anti-HCV in males was $3.7 \%$ and in females $1.9 \%(p=0.086$; table 1$)$.

The prevalence of serological markers by age is shown in table 2 . The highest HBsAg positivity rate $(9.6 \%)$ was in group II (21-40 years). In contrast, anti-HBs and anti$\mathrm{HCV}$ rates were highest in the age-group III (41-60 years). HBsAg prevalence in the age-group of 21-40 years was significantly higher than that in the age-group of $0-20$ years and in those aged 61 and over.

Table 2. The age distribution of patients

\begin{tabular}{|c|c|c|c|c|c|c|c|c|c|c|}
\hline \multirow[t]{2}{*}{ Age-groups } & \multicolumn{2}{|c|}{ HBsAg } & \multirow{2}{*}{$\begin{array}{l}\text { Significance } \\
\text { (group vs. mean } \\
\text { HBsAg) }\end{array}$} & \multicolumn{2}{|c|}{ Anti-HBs } & \multirow{2}{*}{$\begin{array}{l}\text { Significance } \\
\text { (group vs. mean } \\
\text { anti-HBs) }\end{array}$} & \multicolumn{2}{|c|}{ Anti-HCV } & \multirow{2}{*}{$\begin{array}{l}\text { Significance } \\
\text { (group vs. mean } \\
\text { anti-HCV) }\end{array}$} & \multirow[t]{2}{*}{ Total } \\
\hline & $\mathrm{n}$ & $\% \mathrm{a}^{\mathrm{a}}$ & & $\mathrm{n}$ & $\%$ & & $\mathrm{n}$ & $\%$ & & \\
\hline I ( $<20$ years) & 5 & 2.8 & $\mathrm{p}=0.061$ & 32 & 18.2 & $\mathrm{p}=0.0075(\mathrm{~s})$ & 2 & 1.1 & $\mathrm{p}=0.414$ & 175 \\
\hline II (21-40 years) & 43 & 9.6 & $\mathrm{p}=0.0562$ & 121 & 27 & $\mathrm{p}=0.664$ & 4 & 0.8 & $\mathrm{p}=0.070$ & 447 \\
\hline III ( $41-60$ years) & 25 & 5.8 & $\mathrm{p}=0.645$ & 142 & 33 & $\mathrm{p}=0.039(\mathrm{~s})$ & 16 & 3.7 & $p=0.166$ & 425 \\
\hline IV ( $>61$ years $)$ & 4 & 3.6 & $\mathrm{p}=0.230$ & 31 & 28.1 & $\mathrm{p}=0.828$ & 6 & 5.4 & $\mathrm{p}=0.117$ & 110 \\
\hline Total & 77 & 6.6 & & 326 & 28.1 & & 28 & 2.4 & & 1,157 \\
\hline
\end{tabular}

Group I vs. group II HBsAg: $\mathrm{p}=0.004$ (very significant).

Group II vs. group III HBsAg: $p=0.044$ (significant).

Group III vs. group IV HBsAg: $p=0.361$ (NS).

a Gives the percentage of the total in that age-group. 
Table 3. The distribution of subjects according to risk groups

Table 4. The distribution of subjects according to their professions

Table 5. The distribution of subjects according to the places of birth

\begin{tabular}{lccc}
\hline Risk groups & HBsAg & Anti-HBs & Anti-HCV \\
\hline Dental procedures $(\mathrm{n}=158)$ & $18(11.3 \%)^{\mathrm{b}}$ & $75(47.4 \%)$ & $7(4.4 \%)$ \\
Surgery $(\mathrm{n}=89)$ & $9(10.1 \%)$ & $23(25.8 \%)$ & $3(3.3 \%)$ \\
Gynecological interventions $(\mathrm{n}=15)$ & $1(6.6 \%)$ & $7(46 \%)$ & 0 \\
Blood transfusion $(\mathrm{n}=4)$ & 1 & 0 & 1 \\
Health care workers $(\mathrm{n}=109)$ & $6(5.5 \%)$ & $52(47.6 \%)$ & $1(0.9 \%)$ \\
Relatives of HBV carriers $(\mathrm{n}=247)^{\mathrm{a}}$ & $82(33.4 \%)$ & $57(23.2 \%)$ & $12(4.8 \%)$ \\
Patients with multiple risk factors $(\mathrm{n}=143)$ & $22(15.3 \%)$ & $77(58.3 \%)$ & $12(8.3 \%)$ \\
Patients with no known risk factors $(\mathrm{n}=639)$ & $29(4.5 \%)$ & $47(8.2 \%)$ & $4(0.69 \%)$ \\
\hline
\end{tabular}

Excluded from the statistical analysis.

The percentage value refers to the number of patients in that risk group.

\begin{tabular}{lccr}
\hline Professions & HBsAg & Anti-HBs & Anti-HCV \\
\hline Officials, employees $(\mathrm{n}=230)$ & $23(10 \%)^{\mathrm{c}}$ & $60(26.1 \%)$ & $12(5.2 \%)$ \\
Health care workers $(\mathrm{n}=109)$ & $7(6.4 \%)$ & $52(47.7 \%)^{\mathrm{a}}$ & $1(0.9 \%)$ \\
Housewives $(\mathrm{n}=526)$ & $27(5.1 \%)$ & $157(29.9 \%)$ & $12(2.3 \%)$ \\
Teachers $(\mathrm{n}=75)$ & $5(6.6 \%)$ & $21(28 \%)$ & 0 \\
Students $(\mathrm{n}=190)$ & $7(3.4 \%)$ & $30(17.6 \%)^{\mathrm{b}}$ & $2(1.1 \%)$ \\
Policemen $(\mathrm{n}=27)$ & $8(29 \%)$ & $6(27.2 \%)$ & $1(3.7 \%)$ \\
\hline Total $(\mathrm{n}=1,157)$ & $77(6.6 \%)$ & $326(28.1 \%)$ & $28(2.4 \%)$
\end{tabular}

a Health care workers' anti-HBs vs. mean anti-HBs: $\mathrm{p}<0.0001$.

b Students' anti-HBs, vs. mean anti-HBs: $\mathrm{p}=0.0026$. Other comparisons are not significant.

c The percentage value relates to the total number of patients in that professional group.

\begin{tabular}{lrrr}
\hline Place of birth & \multicolumn{1}{l}{ HBsAg } & Anti-HBs & Anti-HCV \\
\hline Marmara region $(\mathrm{n}=371)$ & $17(4.5 \%)$ & $106(28.5 \%)^{\mathrm{b}}$ & $7(1.8 \%)$ \\
Ege region $(\mathrm{n}=49)$ & $2(4 \%)$ & $12(24.4 \%)$ & $2(4 \%)$ \\
Mediterranean region $(\mathrm{n}=38)$ & $2(5.2 \%)$ & $10(26.3 \%)$ & $2(5.2 \%)$ \\
Black Sea region $(\mathrm{n}=274)$ & $20(7.3 \%)$ & $66(24 \%)$ & $8(2.9 \%)$ \\
Middle Anatolia $(\mathrm{n}=139)$ & $9(6.4 \%)$ & $38(27.3 \%)$ & $2(1.4 \%)$ \\
Eastern Anatolia $(\mathrm{n}=153)$ & $12(7.8 \%)$ & $44(28.7 \%)$ & $4(2.6 \%)$ \\
Southeastern Anatolia $(\mathrm{n}=79)^{\mathrm{a}}$ & $10(12.6 \%)$ & $28(35.4 \%)$ & $1(1.2 \%)$ \\
Bulgaria $(\mathrm{n}=54)$ & $5(9.2 \%)$ & $22(40.7 \%)$ & $2(3.7 \%)$ \\
\hline Total $(\mathrm{n}=1,157)$ & $77(6.6 \%)$ & $326(28.1 \%)$ & $28(2.4 \%)$ \\
\hline
\end{tabular}

a Marmara region vs. southeastern Anatolia HBsAg: $p=0.015$.

b The percentage relates to the total number of patients born in the corresponding area. 
The distribution of subjects according to risk groups is shown in table 3 . HBsAg positivities in patients who had a surgical operation and dental intervention previously were higher than the mean HBsAg prevalence of the patients with no risk $(p=0.03, p=0.002)$. Anti-HBs positivity rates in the patients who had dental procedures, surgery, gynecological interventions, and in health care workers were significantly higher than the mean anti-HBs rate for all groups. Anti-HCV showed a similar pattern as antiHBs for patients who had dental procedures and surgical operations. The HBsAg prevalence in the patients with multiple risk factors was significantly higher than in those with no known risk $(\mathrm{p}<0.0001)$.

The distribution of subjects according to professions is shown in table 4. For HBsAg, no significant difference was observed between the various professional groups, except for the policemen who were mostly from southeastern Anatolia with high rate of HBV infection. Health care workers showed significantly higher and students lower anti-HBs positivity rate than the other professions.

The distribution of subjects according to places of birth is given in table 5. The highest HBsAg positivity rates (12.6 and 9.2\%) were found in those from southeastern Anatolia and those who migrated from Bulgaria and the lowest rate $(4 \%)$ in those who were born in the Aegean region. The HBsAg rate in the people from southeastern Anatolia was significantly higher than that in people from the Marmara region $(\mathrm{p}=0.015)$.

\section{Discussion}

The hepatitis B infection is among the important community health problems in Turkey [4]. Although an extensive vaccination program for neonates was established in 1998, its benefits have not been achieved yet. In our study, the rate of HBV carriers in a population of 1,157 was found to be $6.6 \%$. This value is consistent with some previous findings reported in Turkey [1]. As our study population consisted of patients living in Istanbul most of whom came from different parts of the country, our results are expected to show some differences from the mean rates observed for different regions of the country. In the normal population, a HBsAg positivity of 3.4 and 14\% was reported from Izmir in 1995 and from Gaziantep in 1996, respectively [1]. A study of pregnant women in 1995 reported the HBsAg prevalence to be $4.2 \%$ [5]. It is accepted that in Turkey, the rate of HBsAg positivity, based on the use of the ELISA method, is between 3.9 and $12.5 \%$ [1]. On the basis of these rates, Turkey is included in the medium endemicity region. Of the countries with which Turkey has frontiers, Cyprus, Iraq, and the United Arab Emirates have intermediate endemicity, while Bahrain, Iran, Israel and Kuwait are areas of low endemicity [6].

In this study, HBsAg positivity increased with age (table 2); this finding is similar to the previous studies in Istanbul where the hepatitis A seroprevalence increased with age while hepatitis B seroprevalence had not changed $[7,8]$. These findings indicate the importance of horizontal transmission of HBV [8].

It is known from previous studies that being the relative of a HBV carrier constitutes the highest risk factor for HBV infection [9]. In our study, in 247 patients who were close relatives of hepatitis B carriers, the HBsAg positivity was $33.4 \%$ consistent with the previous report [9]; apparently horizontal contamination takes the lead in terms of HBV infection in Turkey as previously reported [6]. The risk of infection was also high within the families who live together in crowded homes, particularly in those parts of the society with low socioeconomic levels (table 4).

The health care workers, who are considered to be among the important risk groups in terms of HBV infection $[10,11]$, did not show statistically significant variation from other groups in terms of HBsAg positivity (table 3$)$. Anti-HBs positivity $(47.6 \%)$ was significantly higher than the mean anti-HBs rate $(28.1 \%, \mathrm{p}<0.0001)$. According to a published study, the rates of HBsAg positivity in the health care workers in Turkey vary between 2.0 and $14.3 \%$, similar to our result of $5.5 \%$, and anti-HBs positivity rates between 11.4 and $56 \%$, also consistent with our finding of $47.6 \%$ [1]. Despite a number of protective measures taken against $\mathrm{HBV}$ and $\mathrm{HCV}$ infections in hospitals and other health institutions, it is obvious that a sufficient level of protection had not been achieved. For example, in this study, the rate of hepatitis $B$ vaccination among health care workers was $11 \%(12 / 109)$, and in all the subjects, it was $4.5 \%$. This is apparently unsatisfactory.

The HBsAg positivity (12.6\%, table 5) of this study in southeastern Anatolia is similar to that reported previously (14.3\%) [1] but the anti-HBs (35.4\%) is lower than the $50 \%$ reported in Gaziantep, a big city in southeastern Anatolia [1]. In these parts of the country, people tend to live together as crowded families and sanitary facilities are still far from adequate, a factor that makes the contamination easier. Of the three markers, anti-HBs was highest in all regions, indicating that HBV infection occurs more frequently in these regions than $\mathrm{HCV}$. 
When our patients were classified according to the risk factors, those with a history of surgical operations $(\mathrm{p}<$ $0.0001)$, dental interventions $(\mathrm{p}=0.001)$ and multiple risk factors $(p<0.0001)$ showed a significantly higher anti$\mathrm{HCV}$ prevalence than the patients with no known risk. But like HBsAg, anti-HCV was not high in health care workers.

\section{References}

1 Badur S: Viral Hepatitis in Turkey; in Kilicturgay K (ed): Viral Hepatitis. Istanbul, Nobel Tip Kitapevi, 2001, pp 15-22.

2 Carpenter AB: Enzyme linked immunoassays; in Rose NR, Macario EC, Folds JD, Lane HC, Nakamura RM (eds): Manual of Clinical Laboratory Immunology. Washington, ASM Press, 1997, pp 20-29.

3 Nie NH, Hull CM, Jenkins JG, Steinbrennar K, Benta DM: Statistical Package of the Social Sciences, ed 2. New York, McGraw-Hill, 1975.

4 Uzunalimoglu O, Yurdaydaydin C, Cetinkaya H, Bozkaya H, Colakoglu S, Tankurt E, Sarioglu M, Ozenirler S, Akkiz H, Degertekin H, Okten A: Risk factors for hepatocellular carcinoma in Turkey. Dig Dis Sci 2001;46:10221028 .

\section{Conclusion}

The present findings showed that HBV seroprevalence was higher than $\mathrm{HCV}$ seroprevalence in the population of Istanbul included in this study, and it tended to increase with age.
5 Kuru U, Turan O, Saglam Z, Ceylan Y, Nurluoglu M, Agacfidan A: Prevalence of hepatitis virus infection in pregnant women and their families. Eur J Microbiol Infect Dis 1996;15: 248-251.

6 André F: Hepatitis B epidemiology in Asia, the Middle East and Africa. Vaccine 2000; 18(suppl 1):S20-S22.

7 Sidal M, Unuvar E, Oguz F, Cihan C, Onel D, Badur S: Age-specific seroepidemiology of hepatitis $\mathrm{A}, \mathrm{B}$, and $\mathrm{E}$ infections among children in Istanbul, Turkey. Eur J Epidemiol 2001;17: 141-144.
8 Degertekin H, Tuzcu A, Yalcin K: Horizontal transmission of HBV infection among students in Turkey. Public Health 2000;114:411-412.

9 Daw MA, Siala IM, Warfalli MM, Muftah MI: Seroepidemiology of hepatitis B virus markers among hospital health care workers: Analysis of certain potential risk factors. Saudi Med J 2000;21:1157-1160.

10 Weiss Y, Rabinovitch M, Cahaner Y, Noy D, Siegman-Igra Y: Prevalence of hepatitis B virus markers among hospital personnel in Israel: Correlation with some risk factors. J Hosp Infect 1994;26:211-218.

11 Al-Sohaibani MO, al-Sheikh EH, al-Ballal SJ, Mirghani MA, Ramia S: Occupational risk of hepatitis B and C infections in medical staff. $\mathrm{J}$ Hosp Infect 1995;31:143-147. 